\title{
Using of system SurveNIR for identification of plastics in library collection
}

\author{
Petra Vávrová $\varangle$, Jitka Neoralová, Magda Součková, Vítězslav Knotek, \\ Nikola Šipošová, Dana Novotná
}

\author{
Vávrová Petra, \\ The National Library of the Czech Republic, \\ Klementinum 190, 110 00, Prague 1, Chech, \\ Director of Collections Preservation Division \\ ORCID: 0000-0001-9452-630X \\ e-mail: petra.vavrova@nkp.cz

\section{Neoralová Jitka,} \\ The National Library of the Czech Republic, \\ Klementinum 190, 110 00, Prague 1, Chech, \\ Head of Department of Development and \\ Research Laboratories \\ ORCID: 0000-0002-2407-3584
}

\section{Součková Magda,}

The National Library of the Czech Republic, Klementinum 190, 110 00, Prague 1, Chech, Researcher, Department of Development and Research Laboratories, Collection Preservation Division

ORCID: 0000-0002-4075-1680

\section{Knotek Vítězslav,}

The National Library of the Czech Republic, Klementinum 190, 110 00, Prague 1, Chech, Researcher, Department of Development and Research Laboratories,

Collection Preservation Division

ORCID: 0000-0002-2358-960X

\section{Šipošová Nikola,}

The National Library of the Czech Republic, Klementinum 190, 110 00, Prague 1, Chech, Researcher, Department of Development and Research Laboratories,

Collection Preservation Division

ORCID: 0000-0001-6264-2453

\section{Novotná Dana,}

The National Library of the Czech Republic, Klementinum 190, 110 00, Prague 1, Chech, Head of Department of Preventive Conservation, Collection Preservation Division

\begin{abstract}
The paper describes qualitative methods of modern library collections (produced after the year 1800) survey in The National Library of the Czech Republic in Prague. Each book is primarily composed of paper sheets and bookbinding. In modern library collections bookbinding usually contains parts composed of synthetic materials. Different types of materials have different mechanisms of degradation. Therefore, the main objectives of this work are nondestructive identification of synthetic materials in bookbinding, their degradation processes, and methods of conservation, conditions of storage, and preventive care as well. Based on the preliminary results of the collection survey in the National Library of the Czech Republic, the most usual types of synthetic materials in bookbinding are cellulose nitrate, cellulose acetate, polyethylene, polyurethane, polymethylmethacrylate, and polyvinyl chloride, both of solid and plasticized type. For faster survey of the collections and deeper information is used new instruments for modern library collection survey and preservation - SurveNIR measuring system. SurveNIR measuring system is used for determination of paper properties and identification of plastic materials using chemometric and comparison with material standards. It can identify more than 45 different types of plastics. It is a nondestructive method, very fast, and it is possible to obtain results in a few seconds of measuring. The SurveNIR system was developed in the European project.
\end{abstract}

Keywords: SurveNIR, measuring system, plastic, polymer, identification, modern library collection

Citation: Vávrová P., Neoralová J., Součková M., Knotek V., Šipošová N., Novotná D. Using of system SurveNIR for identification of plastics in library collection. Bibliosphere. 2021. № 1. P. 54-62. https://doi.org/10.20913/1815-3186-2021-1-54-62. 


\title{
Использование системы SurveNIR для обнаружения пластических материалов в библиотечном фонде
}

\author{
П. Ваврова $\sharp$, Ж. Неоралова, М. Сучкова, В. Кнотек, Н. Шипошова, Д. Новотна
}

\section{Ваврова Петра,}

Национальная библиотека Чешской Республики, Klementinum 190, 110 00, Прага, Чехия, директор отделения сохранности фонда ORCID: 0000-0001-9452-630X

e-mail: petra.vavrova@nkp.cz

\section{Неоралова Житка,}

Национальная библиотека Чешской Республики, Klementinum 190, 110 00, Прага, Чехия, руководитель отдела развития и исследовательских лабораторий

ORCID: 0000-0002-2407-3584

\section{Сучкова Магда,}

Национальная библиотека Чешской Республики, Klementinum 190, 110 00, Прага, Чехия, научный сотрудник отдела развития и исследовательских лабораторий, отдел сохранности фондов

ORCID: 0000-0002-4075-1680

\section{Кнотек Витезслав,}

Национальная библиотека Чешской Республики, Klementinum 190, 110 00, Прага, Чехия, исследователь отдела развития и исследовательских лабораторий,

отдел сохранности фондов

ORCID: 0000-0002-2358-960X

\section{Шипошова Никола,}

Национальная библиотека Чешской Республики, Klementinum 190, 110 00, Прага, Чехия, научный сотрудник отдела развития и исследовательских лабораторий, отдел сохранности фондов

ORCID: 0000-0001-6264-2453

\section{Новотна Дана,}

Национальная библиотека Чешской Республики, Klementinum 190, 110 00, Прага, Чехия, руководитель отдела превентивной консервации, отдел сохранности фондов
Аннотация. В статье описываются качественные методы обследования современных библиотечных фондов (сформированных после 1800 г.) в Национальной библиотеке Чешской Республики в Праге. Каждая книга состоит в основном из бумажных листов и переплета. В современных библиотечных фондах он обычно содержит детали, изготовленные из синтетических материалов. Различные типы материалов имеют различные механизмы деградации. Поэтому основными задачами данной работы являются неразрушающая идентификация синтетических материалов в переплетах, процессов их деградации, а также методов консервации, условий хранения и профилактического ухода. По предварительным результатам обследования фонда в Национальной библиотеке Чешской Республики, наиболее распространенными видами синтетических материалов в переплетном деле являются нитрат целлюлозы, ацетат целлюлозы, полиэтилен, полиуретан, полиметилметакрилат и поливинилхлорид, как твердого, так и пластифицированного типа. Для более быстрого обследования коллекций и более глубокой информации используется новый инструмент для современного обследования и сохранения библиотечного фонда - измерительная система SurveNIR. Она используется для определения свойств бумаги и идентификации пластических материалов с помощью хемометрии и сравнения с эталонами материалов и может идентифицировать более 45 различных типов пластмасс. Это неразрушающий быстрый метод, который позволяет получить результаты за несколько секунд измерения. Система SurveNIR была разработана в рамках европейского проекта.

Ключевые слова: SurveNIR, измерительная система, пластик, полимер, идентификация, современный библиотечный фонд

Для цитирования: Ваврова П., Неоралова Ж., Сучкова М., Кнотек В., Шипошова Н., Новотна Д. Использование системы SurveNIR для обнаружения пластических материалов в библиотечном фонде // Библиосфера. 2021. № 1. C. 54-62. https://doi. org/10.20913/1815-3186-2021-1-54-62. 


\section{Introduction}

Plastics are liable to degradation owing to physical, chemical, and biological factors, as all organic materials of collection objects are. Relative significance of various degradation factors depends on the polymer type, additives, and conditions of its processing. Further, the rate of degradation is influenced by the function of the object before placing it to the collection institution, and conditions, under which they are exhibited and deposited on a long-term basis after it. During their lives, physical and chemical changes occur, which lead to resulting loss of function, shape, and of meaning (Shashoua, 2008). In literature (Shashoua, 2008), four synthetic materials are indicated as more susceptible to degradation, it concerns softened polyvinyl chloride (PVC), polyurethane foam, cellulose acetate and nitrate. Degradation products of these synthetic materials may damage other synthetic materials in their surroundings. Also first plastics are marked with instability, which is most likely caused by wrong stabilization, and to some extent by experimental formula (Williams, 2002).

A survey of physical conditions of book collections with a view to plastic elements was in progress in the National Library of the Czech Republic (NL CR) in 2014 to 2020. A type of synthetic material and typical damages, which can be found in the collection, is observed. The survey proceeds in the Universal Collection and in the National Archival Collections (i.e. the archival collection of domestic and foreign Bohemical documents, both printed and non-printed ones, including the periodical literature). Finding books is very problematic, because press-marks are not thematically allocated in NL CR.

Many synthetic components or parts were found on bookbindings in the collections. Synthetic materials on facing can be found on book covers. Most often it concerns artificial leather, varnished paper, and laminated paper. Further, special bookbindings V9 and V9a (bindings with covers from PVC), mechanical coil binding, and bookbinding screws can be found. Various synthetic dust-covers are used to be supplied secondarily, so that smudging and damaging of books does not occur. Attachments to archived documents, e.g. toys, slides, etc., form a heterogeneous group.

\section{Non-destructive identification - spectroscopic methods}

Spectroscopic methods suitable for identification of bookbinding materials represent in most cases non-destructive and non-invasive methods (without taking of samples). First of all it concerns near infrared spectroscopy (NIR), spectroscopy in visible and ultraviolet radiation (UV-Vis), infrared spectroscopy with Fourier transformation (FTIR), and Raman spectroscopy.
Plastics are rarely used in a clean form. In overwhelming majority, most of them contain all sorts of additives, as filling agents, pigments, dyes, plasticizers, antioxidants, antidegradants, etc. For complete description of plastic bookbinding composition, it is practically impossible to suffice only with non-destructive and non-invasive analytical methods. Nevertheless, instruction for the procedure of finding complete composition of plastics is not a subject of this method.

\section{SurveNIR system}

The SurveNIR system was developed for investigation of physical conditions of paper in extensive archives and library collections. More frequent need of detailed knowledge of material composition of these collections was the use of the instrument extended also to synthetic materials. Though they occur in collections to a smaller extent, however, the rate of their degradation, specificity of manifestation of plastic materials decomposition, and their influence on surrounding materials, supported expansion of SurveNIR system functions just in this direction. In contrast to paper, where a wide spectrum of properties is assessed ( $\mathrm{pH}$ value, composition, mechanical properties, etc.), in case of synthetic polymers, the system identifies group and type of plastics, or whether it is softened or contains fire retardants. The system can identify 45 types of polymers. Some plastics may be difficult to identify owing to their selected properties (gloss, structure, material strength, colour and admixtures).

The present pilot database of plastics in the SurveNIR system includes new samples of plastics from manufacturers, without surface treatment, varnishing, colouring, and without damage and degradation. However, examined samples of collection objects are largely damaged by use or naturally aged and degraded. Surface of plastic material is usually in the final phase of production of the object under examination treated e.g. by varnishing and colouring. Polymer itself is usually already in production filled with additives conditioning usable capacity of material properties. Identification by the help of SurveNIR system is in this case only partial information, and should be complemented with further investigation. In materials, which are not included in the database (some cellulose derivatives, india rubber, most synthetic resins, semi plastics, etc.), erroneous identification may occur.

\section{Principle of SurveNIR system}

The measuring SurveNIR system was developed in the Research Project of the $6^{\text {th }}$ Framework Programme of the European Commission (SurveNIR...; Strlic, 2008). The Chemical Faculty of Ljubljana University in Slovenia was the project 
co-ordinator, the Centre for Preservation of Books (Zentrum für Bücherhaltung - ZBF) in Leipzig in Germany, the National and University Library in Ljubljana, the National Archive in the Hague in the Netherlands, the British Library in London, the Victoria and Albert Museum in London, the Swedish National Archive in Stockholm, the National Archive in Dubrovnik in Croatia, and the National Museum of Denmark in Copenhagen participated in development and system testing. The project objectives were to develop a non-destructive method for characterization of historical paper based on NIR spectroscopy, further to develop portable instrument specially designed for workers in practice, and also to develop software, which will enable the user to carry out statistical survey of the collections. All these tasks were successfully realized (Trafela et al., 2007).

The system makes use of spectrometry in the near infrared region (NIR), in the range of wavelengths $780-2500 \mathrm{~nm}$ (wave number 9100-4000 $\mathrm{cm}^{-1}$ ). It consists of a spectrometer, PC, and software for evaluation (Fig. 1).

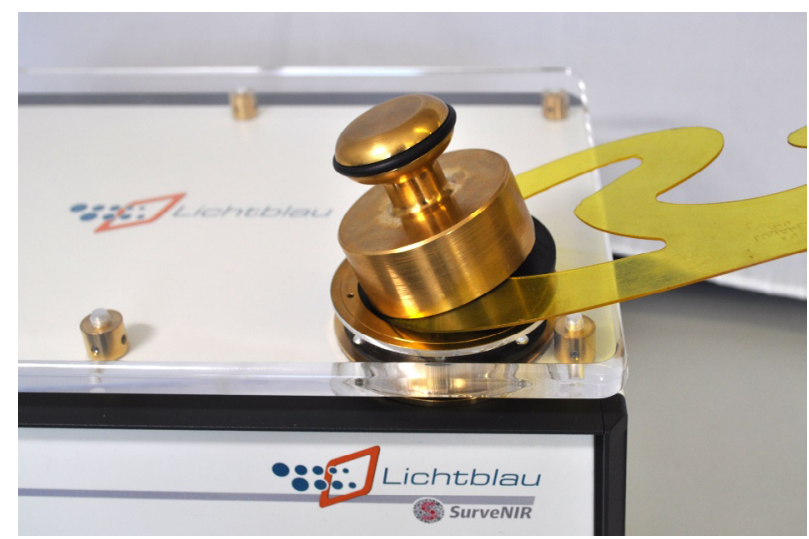

Fig. 1. System SurveNIR

Puc. 1. Система SurveNIR

Acquired NIR spectra of samples are sorted and classified with the use of chemometric methods. For qualitative analysis and identification of synthetic materials, measured spectra of samples are compared with library spectra. Absorption of radiation in NIR region is usually caused by energetic transitions between vibration levels of molecules, namely combinative transitions (coincident excitation of several vibration modes - energy of pertinent transition then corresponds to sum of energy of fundamental transitions of pertinent vibrational modes), and overtones (overtones correspond to excitation of a given vibrational mode to a higher excited level) (Matějka; Siesler, 2002). Absorption bands in the NIR region relate to vibrational levels and overtones of chemical groups $\mathrm{CH}, \mathrm{OH}$, and $\mathrm{NH}$, in which there is the highest intensity of valence vibrations. When incident infrared light irradiates the sample, its beam may be reflected, absorbed, passed through it, or dispersed by the material.
Spectra in the SurveNIR system are acquired by the help of reflexive (diffusion reflective) measurement, when the sample is not collected.

Bands in NIR region are wide, and even in clean materials absorption bands of individual components often overlap, therefore, calibration models are exploited in NIR with the use of advanced chemometric algorithms. Sets of samples for these calibration models contain always more than 45 samples, which are representative enough. It means that they must cover the entire expected or conjecturable variability of characteristics of samples to be analysed.

In light of qualitative information, it is possible to compare measured spectra of clean materials with library spectra, and thus to identity materials. On the basis of statistical evaluation of NIR-spectra of paper, measuring SurveNIR system evaluates its selected chemical and physical and mechanical properties. System SurveNIR uses for sorting and classification of NIR spectra chemometry, method “Partial Least Squares" (Lichtblau, 2009; Strlic, 2008; Strlic et al., 2007, 2009).

Evaluation procedure of paper condition from comprehensive written and book collections by the help of measuring SurveNIR system is described in certified methodology "Survey of condition of paper library collections using measuring SurveNIR system" (Vávrová et al., 2015) a result of the research project „Research, preservation, and care of modern library collections - materials and technologies" (DF13P01OVV04), the programme of applied research and development of national and cultural identity (NAKI), the Ministry of Culture of the Czech Republic,

\section{Polymer identification}

The SurveNIR system can also be used for polymer identification. The measuring set used for paper is in this case expanded by a special extension (Fig. 2). Meanwhile, the system can identify over 45 types of polymers. First of all it concerns copolymers (acrylonitrile) butadiene styrene, polyvinyl chloride, cellulose, cellulose acetate, cellulose triacetate, EPDM rubber, ethylene chlorotrifluoroethylene ECTFE, polyethylene, perfluoroaloxyethylene, polybutene, polycarbonate, polyamide, polyether ether ketone, polyethylene terephthalate, poly lactic acid, polymethylmethacrylate, polyoxymethylene, polyphenylether, polypropylene, silicone, polystyrene, polytetrafluoroethylene, polyurethane, styrene acrylonitrile copolymer, styrene butadiene copolymer. Polymer database continues to extend and upgrade.

For evaluation and sorting spectra, the SurveNIR system makes use of the regression chemometric method "Partial Least Squares" (PLS). In PLS, there are compared the whole spectra (and not absorptions at individual wavelengths) with 


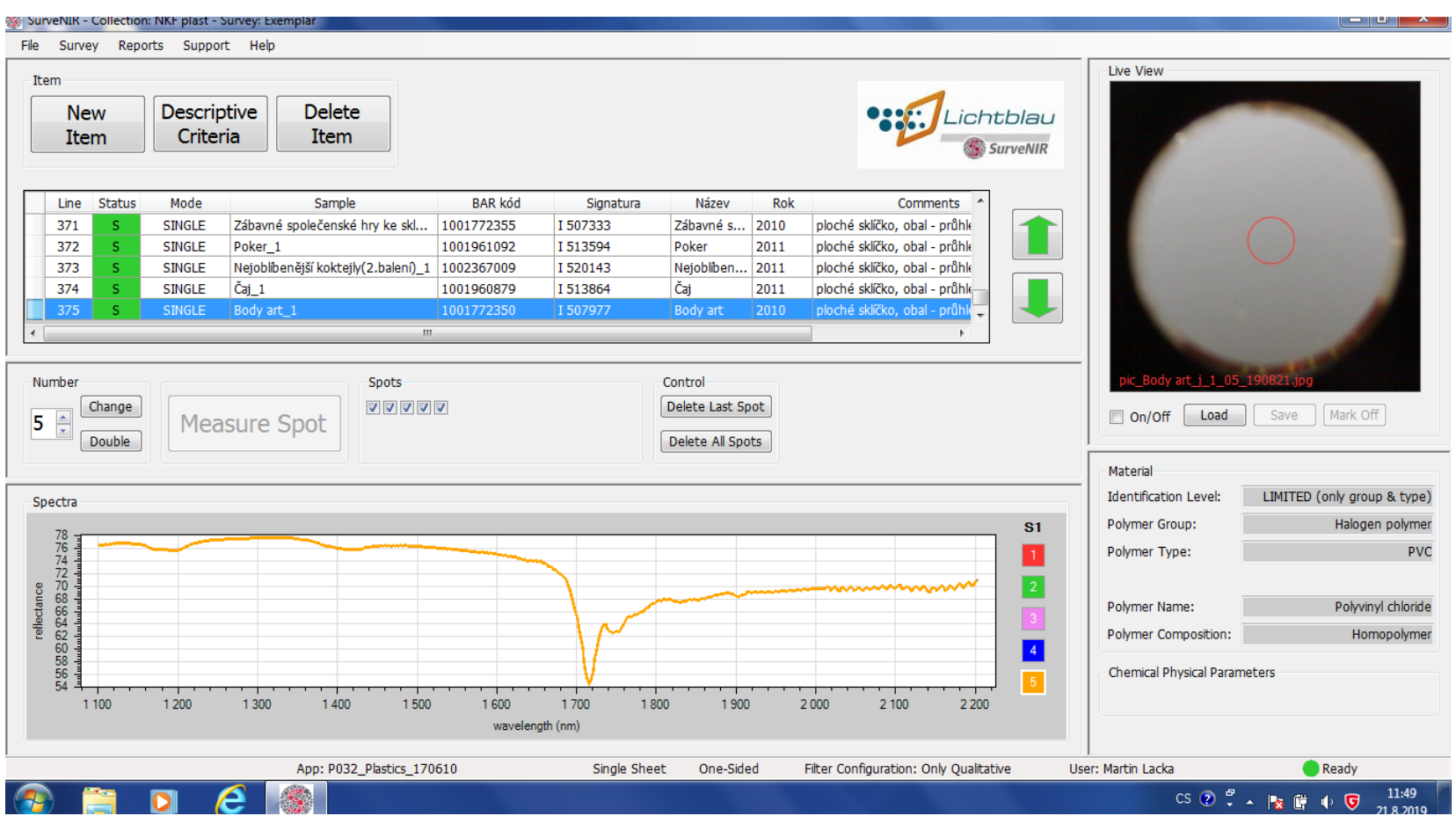

Fig. 2. Diagram and screen of SurveNIR measurement system

Puc. 2. Диаграмма и экран измерительной системы SurveNIR

measured properties, as e.g. content of fire retardants, both acquired from equally large set of samples. This method does not operate with absorbance values in maxima of selected bands, but wider spectral sections or whole spectra are evaluated. The aim is to obtain multidimensional spectral information (represented by a matrix of absorbance values in selected spectral sections for a set of calibration samples), and sample composition (represented by a matrix of concentration of a group of analyte values of interest in the set of calibration samples). Selection of samples for the calibration sets and setting filters of the calibration model is absolutely crucial for use for identification of materials in collections, which already carry marks of usage and natural ageing. Resulting information on classification of measured material to a group and type of synthetic polymers is prediction. In the beginnings of work with supplement to the SurveNIR system for identification of synthetic polymers, it was from this reason necessary to repeatedly optimize parameters of chemometric methods. Correct identification of material by the SurveNIR system is critically dependent also on a type and a number of known samples in the library of spectra. In this case, when samples are evaluated differently from those in calibration sets, predictions may be erroneous.

\section{Description of the equipment}

The SurveNIR measuring system consists of a spectrometer, database of spectra of known samples, and a PC with controlling software. The equipment is portable, equipped with a laptop, for work both in laboratory, and directly in the place of deposition. Safe distance between the object and the measuring orifice (on average $3-4 \mathrm{~mm}$, resolution of $2 \mathrm{~mm}$ ) is ensured by a smooth support plate of plexiglass. Thanks to the finish of measuring surfaces with countersunk little window, this method is suitable for non-destructive analysis of books from collections of any size. Measuring little window is made of high-quality quartz glass, which is standardly used in NIR as fully permeable optical material. The surface of measured material does not need to be treated before. Most plastics used in collections have a surface with expressive reflectance, which is not suitable for measurement, and easily reflect too strong signal exceeding capability of the detector. Therefore, a special stand for measurement in inclination $45^{\circ}$ with sapphire glass is usually installed in place of flat glass. Only if results are not optimum, the sample is measured in horizontal position on the flat little window.

The measuring little window is equipped also with a camera transmitting live image during measurement. Video recording of the point which is being measured, may be created for every measured spectrum. The system makes use of a dispersive spectrophotometer containing a chromatic source of radiation, monochromator, and detector. A halogen lamp and a mirror form instrument measuring head, spectrograph is formed of a filter, holographic concave grating, and a sensor. The measuring head and spectrograph are connected firmly together, the optics is protected from dampness and dust. The dispersive systems represent suitable compromise between equipment size (portability), and spectral 
quality. The source of radiation is the halogen lamp, which covers the visible region as well as an extensive part of the infrared region. White light passes through the sample, and it is then decomposed to individual wavelengths and impinges on a little plate with a large amount of detectors - photodiodes. Relatively narrow, definite wavelength range impinges on every photodiode. The equipment does not contain movable elements, the whole spectrum is measured at a time. Measurement time is shortened from several minutes to fragments of a second, and the measurement is more accurate. Translucent samples need to be measured with a back reflector, which at the same time serves also as paperweight, and protects the samples against shift.

\section{Software functions}

Software enables the user to evaluate individual books, but also conditions of the entire collection. Except the function of synthetic polymer identification itself, it is possible to use the equipment also for statistical evaluation of the collection by determination of index quality. It means determination, what material is for the selected collection endangering, which one is less endangering, or if it has no negative influence on survival of the collection.

For correct evaluation, it is recommended to measure 8 spectra to the average from a homogenous area (i.e. without printing and local contamination), from which at least 5 must be received by the instrument, it means that their deviation ranges within limits of the installed filter. In case of a smaller number of high-quality spectra, measurement should be repeated. The user may also set a lower number of spectra.

Evaluation of spectra is carried out automatically from the entered measurements, and measured values are displayed immediately after measurement. In case that some spectra markedly differ, either instrument excludes them from the evaluation or suggests repetition of measurement (Součková, 2015).

\section{Sample measurement}

Standard measurement on SurveNIR instruments is carried out by passage of radiation through quartz glass on a bedded material, which is placed perpendicularly to the direction of radiation, and weighted/or shielded by the help of back reflector/ weight. However, in identification of plastic materials, the use of a special stand with sapphire glass is preferred for measurement of inclined samples at an angle of $45^{\circ}$, when optimum reflection signal on detector is achieved in most cases. In case of very glossy materials, it is possible to gently move the sample for optimum signal during measurement. In the event of identification of materials in a foil form, it is recommended, with respect to small material thickness and, therefore clearness, to measure more layers of material, for example overlapped or bended. Transparent materials always require a back reflector. For glossy and transparent materials, it is recommended to move the sample during measurement for better detection of spectra.

\section{Limitations}

The instrument incorrectly distinguishes Low-density polyethylene (LD-PE) and High-density polyethylene (HD-PE). In the event of identification of polystyrene (PS), only the group is often identified, therefore, only the presence of styrene units. Identification of materials using reflective method is considerably affected by sample colourfulness and surface properties, especially in very dark and non-transparent samples, reflectance is so low that it is not possible to determine the type of plastics, or plastic material is identified incorrectly.

\section{Method of sample selection}

Library collections may contain from tens to hundreds up to hundreds of thousands even millions of entities. Number of books selected for measurement depends on the size of the collection, but also on the purpose of the survey to be carried out. In case of planning particular restoration or conservation interventions of smaller collections or partial collections, it is advisable to measure all books at random. For evaluation of total conditions and character of extensive collections (tens of thousands to millions of volumes), it is necessary to come up with a selection of optimum samples. The selected set should represent basic characteristics of the entire collection so that it is possible to evaluate findings generally valid for the selected collection on the basis of survey of a smaller set. Books with synthetic elements are often unevenly scattered in collections, therefore, targeted search should be made and all books found measured by the SurveNIR system. Title series form the exception, when identical material is used for binding, and, therefore, only one representative is selected for identification.

\section{Measuring procedure}

In standard measurement on SurveNIR instruments, radiation passes through quartz glass, on which a sample is placed perpendicularly to the direction of radiation, and in measurement of individual sheets shielded by the help of weight. In identification of polymeric materials, the glass is taken off and replaced with a special extension with inclination of $15^{\circ}$. Then NIR spectra are measured, in each sample 3 times, which the instrument averages. The screen after measurement (Fig. 2) displays a table of measured samples, graphic display of 
measured spectra of the actual sample, illustration of place of the last measurement, and the result of polymer identification: classification to a type group (light/dark plastic material), and polymer identification. It is possible to further work with spectra in the programme KustaSpec.

In a lustrous surface, roughing by the help of emery paper or scalpel helps to determine the type of plastic material (Jamborová et al., 2015). If the sample is transparent and thin, it is advisable to fold it for better identification to more layers. Correct evaluation of type of plastic material in transparent materials can also be helped by shielding the sample by the help of weight. In glossy and at the same time transparent materials, probability of correct identification of plastic can be increased by gentle vibration of the sample (in others samples the effect of vibration is insignificant). Spectrum measurement under synchronous vibration of the sample is advisable to apply especially in cases, when the extension for inclination of the sample is not available.

Colourfulness considerably affects identification of samples. Reflectance is so low especially in very dark and opaque samples that it is not possible to determine type of polymer, or evaluation of polymer, due to the absence of stronger filters in software, is incorrect.

\section{Survey and identification of synthetic materials in bookbinding of modern book collections in NL CR by the help of SurveNIR instrument}

The survey was under way in collections of the National Library, which was focused on books (Fig. 3, 4), or their attachments (Fig. 5), which contained materials of synthetic polymers. The collection, on which the survey was carried out, was from the 20th, and especially up to the 21 st centuries, where presence of plastic materials was mostly anticipated. With respect to a large number of books in collections of the National Library, those collections and depositories needed to be guessed containing bigger quantities of books with synthetic materials, and it was thus possible to work with them together. The survey was a continuation to work from the previous years, and included again both analyses for identification of bookbinding materials, and also those of their various supplements. In addition to it, some books themselves did not contain synthetic polymers, but often were packaged in these materials. Enclosures then contained books intended for child readers, or educational books in boxes with additional objects on a given subject. The procedure of survey and documentation comes out from a standard survey of physical conditions of book collections kept by the Central knowledge base of the register of digitization (further in text Agenda)

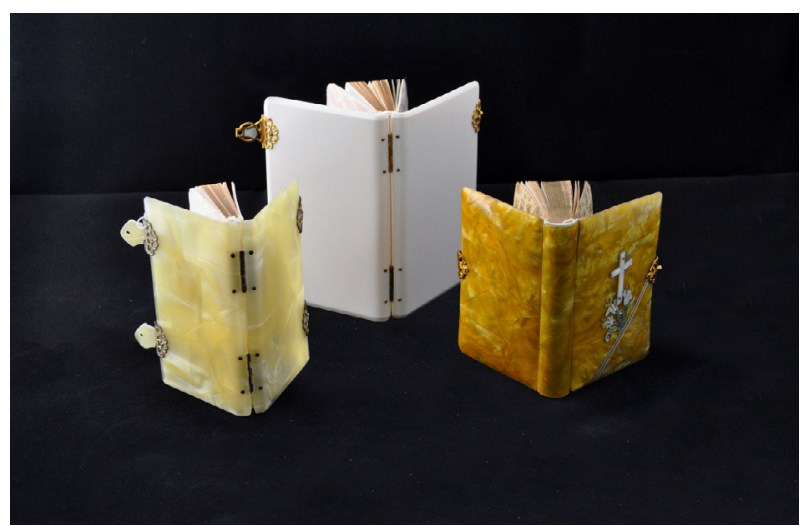

Fig. 3. Different kind of plastic bookbindings in NL CR collections

Puc. 3. Различные виды переплетов из пластика в фонде Национальной библиотеки Чешской Республики

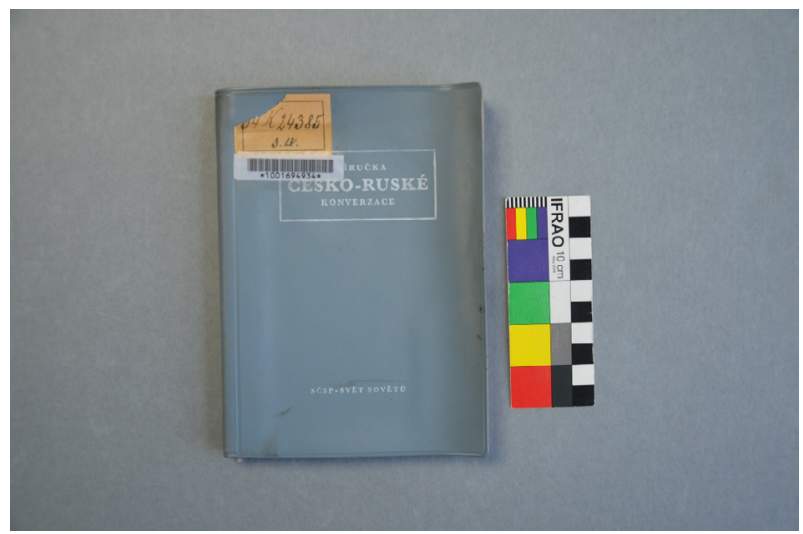

Fig. 4. PVC cover of book

Puc. 4. Обложка книги из поливинилхлорида

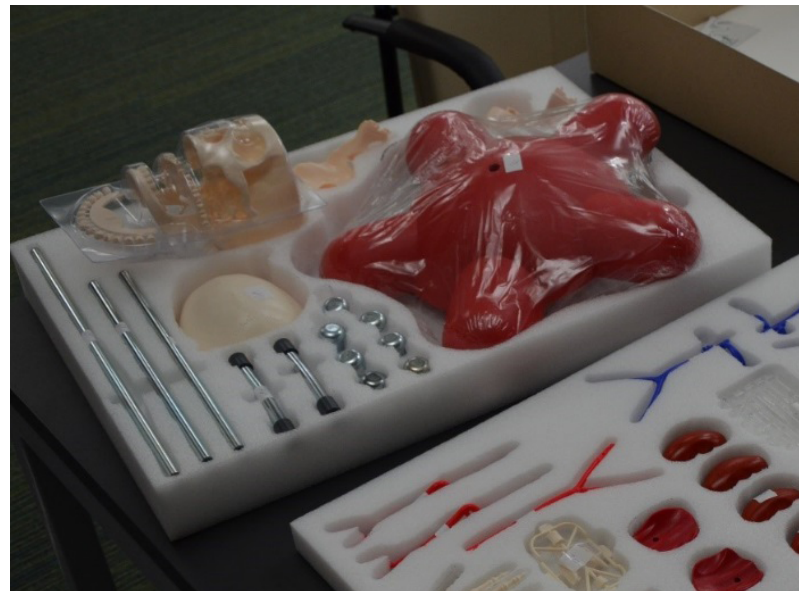

Fig. 5. Attachments of books plastic 3D objects

Puc. 5. 3D-объекты из пластика в приложениях к книгам

book collections of the NL CR with minimum equipment and in the shortest time possible, a method for survey of the collections was developed. It aided the formation of proposals of working procedure of care, conservation, but also preservation of modern collections (Vávrová et al., 2018). 
The most frequent damage of bindings with imitation leather coating is their abrasion and contamination. In an isolated case, degradation of the synthetic layer occurred, which became sticky and fell off. In cases of laminated paper, contamination synthetic layers occur, yellowing, cracks development, and unsticking from paper underlay.

In bindings with cover made of PVC we most often encounter contamination, partial or complete unsticking of end paper from covers, and cover deformation. In smaller extent, scratches, disrupted cuttings and efflorescence (lubricant, plastificator) can be found. Depending on the material surrounding, their sticking to cover made of PVC may occur.

Secondarily supplied book jackets used to be scratchy, contaminated, and cracked. These wraps are not conserved.

\section{Operational procedure}

The survey starts with evidence of bibliographic information and documentation of the book. Every accessible and at first sight visible information is subsequently introduced to the Agenda (information on book, its typology, damage, etc.). If the object has enclosures, they are also photographed, measured, and subsequently mentioned in the relevant form section. Measurement of weight on scale follows, as well as photographic documentation of the object, and $\mathrm{pH}$ measurement of book paper, if it is suitable from view of material finish. This information is then also entered to the Agenda. The next step is analysis of synthetic polymeric materials using the SurveNIR instrument. The measurement is filled up to the programme interface on the notebook connected to the instrument, where there is entered basic information on the book (e.g.: title, or barcode). Subsequently, an analysed book or its part is laid down on flat or oblique glass of the measuring little window of SurveNIR, and then the measurement itself takes place. The result is a curve of dependency of absorbance on wavelength, to which the instrument is in case of successful analysis capable to assign polymeric group, particular type, and complete with information, whether plastic includes plastificator and other additives, or whether it concerns copolymer or not. The measurement is subsequently saved in format pdf, which again contains basic information on the object and a table with results of measurement.

For better lucidity of the measurement in Agenda, a photograph of the screen with measurement is taken, which is together with a pdf file introduced into the Agenda. Verbal evaluation of the measurement is also introduced to the Agenda in section Notes. Before terminations of the session with the SurveNIR instrument, measurements carried out that day are saved in a collective table in the excel software.

\section{Results of collection survey in NL CR}

Within the frame of a project called "Synthetic materials in book collections", the survey of collections of the NL CR is under way. The survey was focused on mapping types of book-bindings containing synthetic materials (plastics, artificial leather, lamination foil), and identification of pertinent damage of given books.

All found book-bindings are entered to a specially generated Excel table containing individual cards for plastics, laminations, and artificial leathers. In laminations and artificial leathers, only damaged bindings are photographed and recorded for speeding the work. During the survey, more than 500 books were found for the day of submission the report and measurements were carried out, out of which 14 of different types of plastics were analysed, containing various types of plastics, out of which $165 \mathrm{x}$ were bindings with plasticized PVC covers. Further, presence of cellulose derivatives was analysed 152x on the whole. It itself is not categorized as polymeric material, indeed, this result was achieved at endeavour to analyse also lamination of covering paper, or envelopes of soft bindings. With respect to thin layers of lamination foil, the equipment detected paper (cellulose) subbase, not synthetic foil itself, and that is why laminations were not henceforth measured.

Peeling of lamination foil from covering paper or book envelopes is very frequent of mechanical damages of binding with laminate covers. Further, contaminations of various origins occur.

A large number of discovered damages was caused apparently by natural ageing or defects from manufacturing. This will be further surveyed in cooperation with colleagues from the Institute of Chemical Technology Prague, department of polymers (Rapouch, Vávrová, 2018).

The survey brought a lot of items of information on synthetic elements in a common library collection and showed that plastic elements of bookbindings are for the present in good conditions. Contamination is common damage in all synthetic materials. It should be necessary to carry out more extensive surveys in the future, for reasons of extensiveness of book collections of NL CR.

\section{Conclusion}

Identification of polymers or plastic materials using measuring by the SurveNIR system is fast and simple, but it is not unimpeachable for the present. For putting identification more precise by this system, further research is underway, and this identification could be yet reliable in the future. Questionable or debatable cases and, e.g. degraded plastic materials are needed then to be analysed using other analytical and also identification methods. Other 
spectroscopic methods, such as infrared or Raman spectroscopy, allow more detailed analysis of materials, including additives and degradation products, but they are difficult for use by conservators and non-scientific library staff. The great advantage of the system SurveNIR is the user-friendly design with automatic evaluation and processing of spectra. The device is portable and compact, without attachments, holders or optical fibers. The shape of the device does not limit the selection of objects for identification. Although the device has certain lim- itations, it is still a good choice for routine research of the physical condition of library collections.

The measuring SurveNIR system was purchased from means of the experimental project of the programme of applied research and development of national and cultural identity (NAKI) "Survey, preservation, and care of modern library collections - materials and technologies" (ID no. DF13P01OVV004) of the Ministry of Culture of the Czech Republic.

\section{Acknowledgement:}

This paper was prepared thanks to financial support of the Ministry of Culture of the Czech Republic in the grant Program of the applied research and development of national and cultural identity (NAKI) in project ID no. DG18P02OVV001 "Synthetic materials in the library collections".

\section{References}

Jamborová T, Benetková B, Neoralová J, Palánková L and Vávrová P (2015) Identifikace plastů knižní vazby pomocí přistroje SurveNIR: závěrečná zpráva DF13P01OVV004. Praha.

Lichtblau D (2009) SurveNIR - non-destructive surveying of paper collections. Advances in paper conservation research. London, pp. 56-60.

Matějka P. Spektrometrie v blízké infračervené oblasti. AnZdoc URL: https://adoc.tips/spektrometrie-v-blizkeinfraervene-oblasti.html (accessed 08.04.2020).

Rapouch K and Vávrová P (eds) (2018) Kapitoly $z$ konzervace a restaurování plastů. Brně: Techn. Muz.

Shashoua Y (2008) Conservation of plastics: materials science, degradation and preservation. London: Elsevier, Butterworth-Heinemann.

Siesler H (2002) Near-infrared spectroscopy: principles, instruments, applications. Weinheim: Wiley-VCH.

Součková M, Palánková L and Neoralová J (2015) Využití měřícího systému SurveNIR pro průzkum stavu papíru knihovních fondů a identifikace polymerů. Neinvazivní metody v péči o kulturní dědictví. Litomyšl: Univ. Pardubice.

Strlic M (2008) NIR/chemometrics approach to characterisation of historical paper and surveying of paperbased collections. 15th Triennial Meeting proceedings. New Delhi, pp. 22-26.

Strlic M, Kolar J and Lichtblau D (2007) The SurveNIR project - a dedicated near infrared instrument for paper characterization. Museum microclimates. Hvidovre, pp. 81-84.

Strlic M, Lichtblau D, Kolar J and Trafela T (2009) SurveNIR project - a dedicated instrument for collection surveys. Advances in paper conservation research. London, pp. 53-55.
SurveNIR: near infrared tool for collection surveying. SurveNIR. URL: http://www.science4heritage.org/survenir/ (accessed 08.04.2020).

Trafela T, Strlic M, Kolar J, Lichtblau DA, Anders M, Mencigar DP and Pihlar B (2007) Non-destructive analysis and dating of historical paper based on IR spectroscopy and chemometric data evaluation. Analytical Chemistry 79 (16): 6319-6323. DOI: 10.1021/ ac070392t.

Vávrová $\mathrm{P}$, Neoralová J, Boumová K, Součková M, Mračková L, Hřebecká D, Kaštáková T and Sazamová T (2018) Opravy plastových vazeb novodobých knihovních fondů - konzervace novodobých knižních vazeb s plastovými prvky, čištění knižních vazeb vyrobených z PVC, preventivní konzervace. NUSL digital repository. URL: http://invenio.nusl.cz/record/386298?ln=cS (accessed 22.06.2020).

Vávrová P, Palánková L and Sedliská H (2013a) Průzkum fyzického stavu novodobých knihovních fondů v Národní knihovně ČR: nový nástroj. Časopis Národního muzea, řada historická. 183 (3/4): 48-53.

Vávrová P, Polišenský J, Kocourek P and Sedliská H (2013b) Metodika průzkumu fyzického stavu novodobých knihovních fondů. NUSL digital repository. URL: http://invenio.nusl.cz/record/253544? In=cs (accessed 15.04.2020).

Vávrová $\mathrm{P}$, Součková $\mathrm{M}$, Palánková L and Neoralová J (2015) Metodika "Průzkum stavu papíru knihovních fondů měřícím systémem SurveNIR". NUSL digital repository. URL: http://www.nusl.cz/ntk/nusl-253556 (accessed 15.04.2020).

Williams RS (2002) Care of plastics: malignant plastics. WAAC Newsletter, 24 (1). URL: https://cool.culturalheritage.org/waac/wn/wn24/wn24-1/wn24-102.html (accessed 22.06.2020). 